\title{
Rheological, pasting and sensory properties of biscuits supplemented with grape pomace powder
}

\author{
Wenjuan LOU ${ }^{1,2,3}$ (D), Haixu ZHOU ${ }^{1,3}$, Bo LI ${ }^{1,3 *}$, Grevtseva NATALIYA ${ }^{4}$
}

\begin{abstract}
The research aimed to study the effects of $0-20 \%$ substitution of wheat flour with grape pomace powder (GPP) on the rheological and pasting properties of wheat dough, and on sensory properties, digestive and antioxidant activities of the prepared biscuits. The results of rheological analysis showed that incorporation with GPP concluded in reduced water absorption (WA) and increased dough stability. Rapid visco-analyser (RVA) results suggested GPP could increase the breakdown value of the starch paste system but decrease the setback and peak viscosity. With respect to biscuit properties, it was found that $5 \%-15 \%$ GPP resulted in increased chewiness and hardness of biscuits. Also, it was recorded that GPP significantly improved antioxidant activity and DPPH and hydroxyl radical scavenging capabilities. Although the in vitro digestibility results showed that the addition of GPP displayed minor influence on digestion rate, the sensory analysis results showed that the biscuits supplemented with GPP to a level of $10 \%$ resulted in products with good overall acceptability. Additionally, biscuits incorporated with an addition amount of 10\% GPP exhibited nailing oxidation resistance and can be considered as a food with a high fiber content, which is a good option for people to pursue modern healthy foods.
\end{abstract}

Keywords: grape pomace; biscuit; dough properties; antioxidant activities; digestibility.

Practical Application: This work is expected to deliver reasonable guidance on the addition of grape pomace powder into wheat flour for food production. One can envision that appropriately using grape pomace powder in food processing for nutritional value enhancement and popularity improvement will boost the grape economy, reduce resource waste, and even solve environmental problems related to direct disposal.

\section{Introduction}

Grape is one of the most abundant fruits and approximately $80 \%$ are used in the winemaking industry annually (Mildner-Szkudlarz et al., 2013). Approximately 20\% (by weight percentage) of this is transformed into grape pomace (GP) as a by-product, which is promising for food fortification. Thus, GP has drawn attention in both academia and industry. It has been estimated that one litre wine generates 17 kilograms of GP. Disposal of GP and associated environmental issues (Tolve et al., 2020) are a considerable challenge because of its under exploitation. Accordingly, effective GP utilization has the potential to reduce waste and concomitantly increase profits, leading to a more sustainable economy.

GP is rich in dietary fiber and polyphenols (Nowshehri et al., 2015). The dietary fiber content is generally $43-75 \%$ by dry weight (Teixeira et al., 2014). Dietary fiber in fruit exerts various beneficial physiological effects, including improving stomach function and postprandial insulin response, and reductions in total cholesterol and low-density lipoprotein cholesterol contents. The polyphenol content varies among grape sources (Chamorro et al., 2021; Liang et al., 2020). This diversity can be explained by (1) intrinsic genetic variation along with differences in maturation stages and agro-climatic conditions and (2) differences in winemaking technologies and/or extraction procedures. Polyphenols mainly include anthocyanins, flavonols, flavanols, phenolic acids, and resveratrol and have various biological activities (e.g. antioxidant, antimicrobial, and anti-inflammatory effects) with potential health benefits under rational utilization (Lee et al., 2009; Mildner-Szkudlarz et al., 2010).

In food fortification, the utilization of valuable components with the potential to promote the specific functionality of products is a key goal to meet the diversified, escalating market demand. In practice, pomace powder and specific component extracts have been utilized as additives for food production. Mango skin powder has been used as an additive in wheat dough and has improved the dietary fiber and antioxidant contents (Ajila et al., 2008). Potato skin powder has been introduced in biscuit production to increase the dietary fiber content (Devinder et al., 2012). Dietary fiber and antioxidant extractives from apple pomace have been shown to impact physicochemical properties of biscuits (Kohajdová et al., 2014). 
To improve the utilization of by-products from food processing and to meet consumer demand for healthy foods, there is growing interest in the application of dietary fiber and natural antioxidants in baked food products (Pasqualone et al., 2014; Anil, 2007; Mildner-Szkudlarz et al., 2013). However, the effects of the partial substitution of wheat flour with grape pomace powder (GPP) in biscuit production are not clearly elucidated. In this study, GPP was added to wheat flour at various ratios for biscuit production and its influence on rheological properties, pasting and aging properties of dough were evaluated. Additionally, its impacts on biscuit nutrition, physicochemical properties, and sensory characteristics were systematically studied. This work is expected to deliver reasonable guidance on the processing of dough-based foods containing GPP. One can envision that appropriately using GPP in food processing for nutritional value enhancement and popularity improvement will boost the grape economy, reduce resource waste, and even solve environmental problems related to direct disposal.

\section{Materials and methods}

\subsection{GP preparation and materials}

GP was derived from a lab-scale winemaking process with Cabernet Sauvignon (grown in Huailai city, Hebei province of China) as a raw material. In brief, grapes were mixed with Saccharomyces cerevisiae and fermented at $25^{\circ} \mathrm{C}$ for 7 days. GP and wine were separated by squeezing. GP was subjected to natural drying to remove $70 \%$ water and then transferred to an oven operated at $60{ }^{\circ} \mathrm{C}$ for $72 \mathrm{~h}$ for further dehydration. GPP was obtained using a high-speed pulveriser (Beijing Zhongxing Weiye Instrument Co., Ltd., Beijing, China), and an 80-mesh filter was used to collect particles, followed by storage at $-20^{\circ} \mathrm{C}$. GPP was composed of crude protein $(13.61 \pm 0.97 \mathrm{~g} / 100 \mathrm{~g})$, dietary fiber $(65.10 \pm 2.1 \mathrm{~g} / 100 \mathrm{~g})$, ash $(5.12 \pm 0.87 \mathrm{~g} / 100 \mathrm{~g})$, crude lipid (17.42 $\pm 1.15 \mathrm{~g} / 100 \mathrm{~g})$, and water $(5.86 \pm 0.55 \mathrm{~g} / 100 \mathrm{~g})$, on a dry weight basis. Low-gluten flour (lipid $0.6 \mathrm{~g} / 100 \mathrm{~g}$, total carbohydrates $78.1 \mathrm{~g} / 100 \mathrm{~g}$, protein $8.3 \mathrm{~g} / 100 \mathrm{~g}$, and $\mathrm{Na} 0.06 \mathrm{~g} /$ $100 \mathrm{~g})$, egg, salt, baking soda, gluconolactone, ammonium acid carbonate, soft sugar, and palm oil were purchased from a local market. Absolute ethyl alcohol (analytical grade) was obtained from Sinopharm Chemical Reagent Co. Ltd. (Shanghai, China).

\subsection{Determination of physicochemical properties of composite flour}

Low gluten wheat flour and GPP were used as raw materials. Various amounts of GPP (i.e. 5, 10, 12.5, and $20 \mathrm{wt} \%$ ) were added to wheat flour and subjected to thorough mixing. Rheological properties were measured according to previously described methods (Girard et al., 2016). Pasting characteristics of the blended flour systems were measured using RVA (TecMaster, Perten Instruments, Warriewood, Australia), with reference to the standard method AACC 76-21 (AACC International, 2000). Each experiment was repeated three times.

\subsection{Biscuit production}

The biscuit recipe consisted of composite flour or wheat flour (57.5 wt\%), water (5.2 wt\%), sugar (20.2 wt\%), palm oil
(4.1 wt $\%)$, egg (8.0 wt $\%)$, milk (2.7 wt $\%)$, baking soda (0.5 wt $\%)$, salt $(0.5 \mathrm{wt} \%)$, gluconolactone $(0.6 \mathrm{wt} \%)$, and ammonium acid carbonate $(0.7 \mathrm{wt} \%)$. The materials were mixed to form a dough, transferred to a mould, and heated for $13 \mathrm{~min}$ in a baking oven, with upper and lower temperatures of $165^{\circ} \mathrm{C}$ and $155^{\circ} \mathrm{C}$, respectively. After biscuits were cooled to room temperature, they were packed. For GC-MS analyses, biscuits were crushed to fine powders and stored in a refrigerator at $-20^{\circ} \mathrm{C}$. For sensory evaluation, biscuits were made on the same day.

\subsection{Sensory evaluation}

Biscuits with various amounts of GPP were evaluated by a quantitative descriptive sensory analysis, using a hedonic 9-point scale as follows: 9, like extremely; 8 , like very much; 7, like moderately; 6 , like slightly; 5 , neither like nor dislike; 4, dislike slightly; 3 , dislike moderately; 2 , dislike very much; and 1, dislike extremely. Twenty participants, aged 19-21, were included. First, sensory attributes and intensity criteria were established. The terms included colour, appearance, flavour, and texture. Second, participants were trained six times (one hour each time) to enable a rational evaluation. Third, biscuits with random codes were randomly placed and evaluated by each member after rinsing the mouth. Sensory evaluation results are described as $x($ mean $) \pm S D(n=3)$.

\subsection{Texture analysis}

Biscuit hardness, fracturability, and chewiness indexes were determined using a TA-XT2i textural analyser (Stable Micro Systems, Surrey, UK). The parameters were as follows: speed before, during, and after the test were 1.0, 1.0, and $2.0 \mathrm{~mm} / \mathrm{s}$, respectively; compression ratio was $70 \%$. Each experiment was repeated three times. The results are expressed as $\mathrm{x}$ (mean) \pm $\mathrm{SD}(\mathrm{n}=3)$.

\subsection{Colour characterization}

Biscuits were made into round slices with a diameter of $2 \mathrm{~cm}$ and thickness of $5 \mathrm{~cm}$. The $L^{*}$ (brightness), $a^{*}$ (red and green chroma), and $b^{\star}$ (yellow and blue chroma) values were determined using an ADCI-60-C automatic colorimeter (Beijing Chentech Instrument Technology Co., Ltd., Beijing, China). For $L^{\star}, 0-100$ represent colours from dark to light. The value of $a^{*}$ indicates the degree of red and green, where high values are associated with red and vice versa. With respect to $b^{\star}$, yellow and blue and indicate high and low values, respectively. Each experiment was repeated three times, and mean values were obtained.

\subsection{Composition analysis}

Water, ash, protein, and lipid contents were measured according to the 44-15, 08-01, 46-11, and 30-10 standards (AACC International, 2000). Total dietary fiber (TDF) was determined by the standard enzymatic-gravimetric method (991.43, 17 $7^{\text {th }}$ edition) recommended by Association of Official Analytical Chemists (AOAC International, 2000). The total 
polyphenol content was measured using a modification of the Folin-Ciocalteu assay (Yang et al., 2010).

\subsection{Digestive characteristics}

The contents of rapidly digestible starch (RDS), slowly digestible starch (SDS), and resistant starch (RS) were determined according to previously proposed methods (Mahasukhonthachat et al., 2010; Englyst et al., 1992), and the reducing sugar content was determined by 3 , 5-dinitrosalicylic acid colorimetry. The equations were as follows:

$$
\begin{aligned}
& S D S(\%)=\frac{(\mathrm{G} 120-\mathrm{G} 20) \times 0.9}{T S} \times 100 \\
& R D S(\%)=\frac{(\mathrm{G} 20-\mathrm{G} 0) \times 0.9}{T S} \times 100 \\
& R S(\%)=\frac{[T S-(\mathrm{SDS}+\mathrm{RDS})] \times 0.9}{T S} \times 100 \\
& \text { Hydrolysis rate }(\%)=\frac{(\text { the weight of hydrolysed glucose }) \times 100}{(\text { thetotal sample weight })}
\end{aligned}
$$

Hydrolysis index $(H I)=\frac{(\text { the area under the hydrolysis rate curve }) \times 100}{(\text { the area under the hydrolysis rate curve of the control group })}$

where $G_{120}, G_{20}$, and $G_{0}$ are the glucose contents (mg) at 120, 20 , and $0 \mathrm{~min}$, respectively; 0.9 is the transformation factor; and TS is the sample weight (mg). The predicted glycaemic index (pGI) was determined by a previously described method (Goñi et al., 1996), and the in vitro simulation of the human intestinal digestive system was used. The hydrolysis rate was fitted by first-order kinetics:

$$
C_{t}=C_{\infty} \times\left(1-e^{-k t}\right)
$$

where $\mathrm{C}_{\infty}$ is the equilibrium concentration and $\mathrm{k}$ is the equilibrium coefficient. The area under the sample hydrolysis curve was calculated as follows:

$$
A U C=C_{\infty}\left(t_{f}-t_{0}\right)-\left(C_{\infty} / k\right)\left[1-e^{-k\left(t_{f}-t_{0}\right)}\right]
$$

where $\mathrm{C}_{\infty}$ is the equilibrium concentration $\left(t_{180}\right), t_{f}$ is the final time (90 $\mathrm{min}), \mathrm{t}_{0}$ is the initial time $(0 \mathrm{~min})$, and $\mathrm{k}$ is the reaction constant.

\subsection{Determination of antioxidant properties}

Briefly, $0.5 \mathrm{~g}$ of sample powder was added to $10 \mathrm{~mL}$ of an $80 \%$ methanol solution at $25^{\circ} \mathrm{C}$ and placed in the dark for extraction for $24 \mathrm{~h}$. The mixture was then centrifuged at $10000 \mathrm{r} / \mathrm{min}$ to obtain the upper supernatant liquid, which was used for subsequent measurement to assess the DPPH radical scavenging ability (Wang et al., 2015), hydroxyl radical scavenging activity (Chimi et al., 1991), and iron ion reducing activity (Sakanaka et al., 2004).

\subsection{Data processing and statistical analysis}

Microsoft Excel 2013 and SPSS 22.0 (SPSS Inc, Chicago, IL, USA) were used for data processing and statistical analyses, respectively. Differences among groups were evaluated by oneway ANOVA, and $\mathrm{p}<0.05$ indicated a significant difference. Origin was used to generate plots.

\section{Results and discussion}

\subsection{Rheological properties of dough}

The effects of various amounts of GPP on the rheological properties of dough are shown in Figure 1. Water absorption indicates the water consumption for dough formation with a certain, targeted density (Moon \& Kweon, 2021). WA of the dough decreased significantly $(p<0.05)$ as the proportion of GPP in wheat flour increased (Figure 1a). The results are different from those of studies using fiber or fiber extractives in composite dough, which increase water absorption (Ar1 Akin et al., 2021; Aly et al., 2021). This difference can be attributed to the fact that lignin, which account for $44 \%$ of grape seed, is insoluble part of dietary fiber in water and has hydrophobic binding ability. This fraction mainly contributes to the decrease of water absorption (Mildner-Szkudlarz et al., 2013). Development time (DT) is the interval between the initial time point and the point at which dough shows the maximum torque. Stability time (ST) is the duration of the maintenance of a constant torque of $1.1 \mathrm{Nm}$ during the kneading process. These two parameters are indicators of dough strength and are positively correlated (Nogueira et al., 2021). As shown in Figure 1c, the DT of dough with GPP was highest at $15 \mathrm{wt} \%$, and the ST increased significantly $(\mathrm{p}<0.05)$ with increasing amounts of GPP, suggesting that GPP could improve the strength of dough and subsequent processing properties. This is probably due to high lipid content in grape seeds, which can form lipoprotein complexes between starch and other hydrophobic gluten components, resulting in dough compaction and stability (Mironeasa et al., 2012; Kuchtová et al., 2018).

In terms of gluten weakening, $\mathrm{C} 2(\mathrm{Nm})$ is the minimum torque value for the sample (e.g. dough) under mechanical agitation and thermal treatment. $\mathrm{C} 1-\mathrm{C} 2(\mathrm{Nm})$ represents the degree of weakening, estimated as the difference between torque at the end of the period of stability at $30^{\circ} \mathrm{C}$ and $\mathrm{C} 2$. It reflects the ability of dough to withstand mechanical agitation and is negatively correlated with $\mathrm{C} 2$, low values correspond to a high gluten strength. As shown in Figure 1b, compared with values in the control group, the C1-C2 values were significantly lower $(\mathrm{p}<0.05)$ in the GPP groups, except for $5 \mathrm{wt} \%$, consistent with $\mathrm{C} 2$ results. These findings suggested that GPP increased the gluten network strength, which might improve the toughness of resulting biscuits and thus decrease brittleness. In addition, polyphenols have a complex influence on dough. There is a tradeoff between their weakening effects associated with disulphide linkage cracking and gluten strength reinforcement via interactions with gluten (Girard et al., 2016; Blanco Canalis et al., 2020; Han \& Koh, 2011). The influence of polyphenols on the final baked food depends on their relative amount, antioxidant capacity, and hydroxy content. When GPP exceeded $5 \mathrm{wt} \%$, increased 
(a)
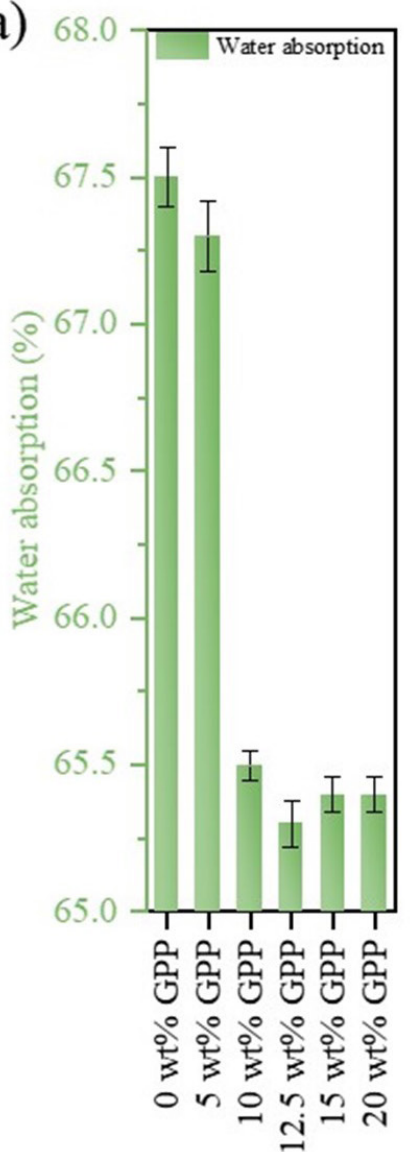

(b)

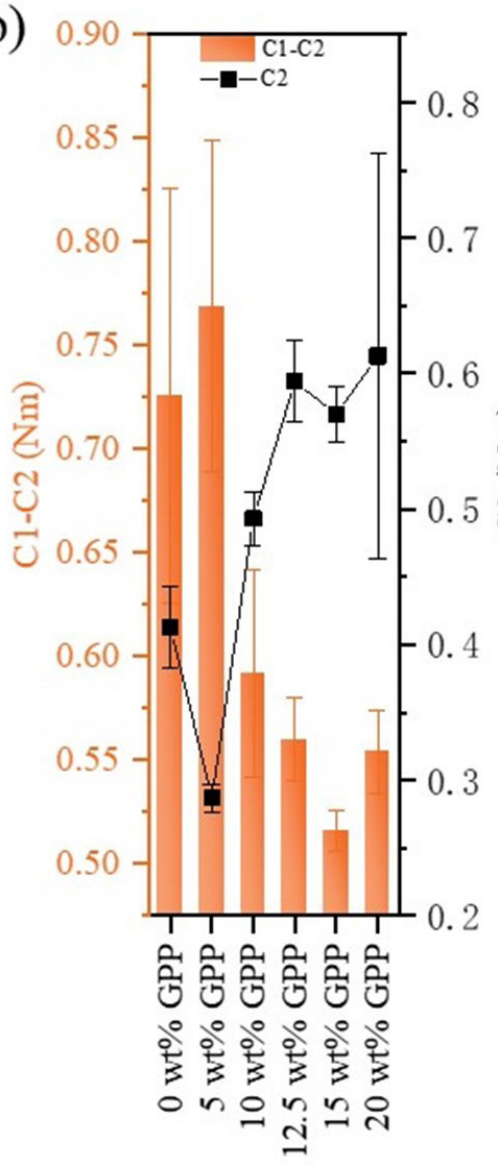

(c)

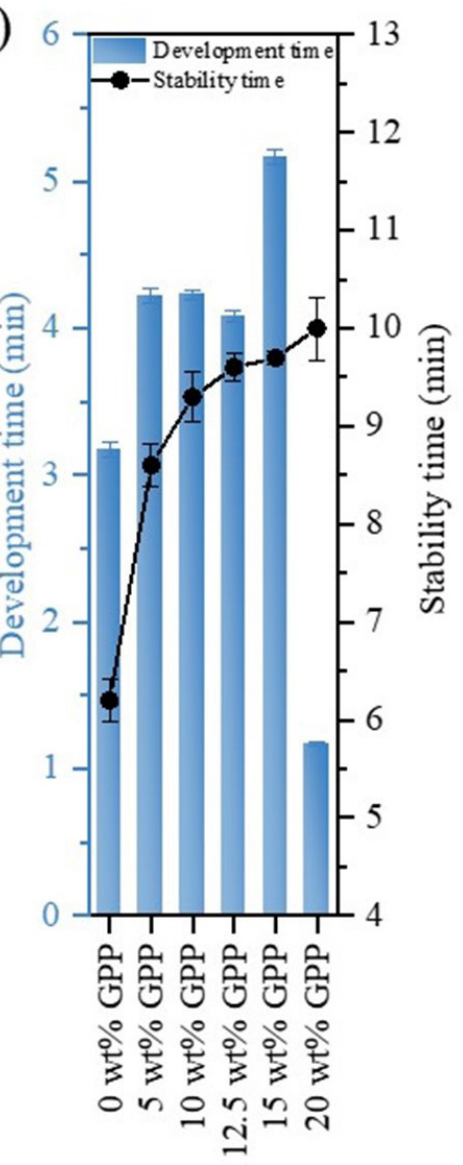

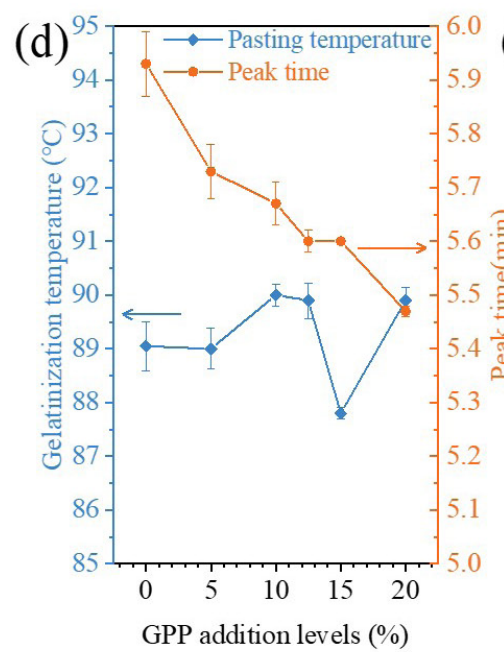
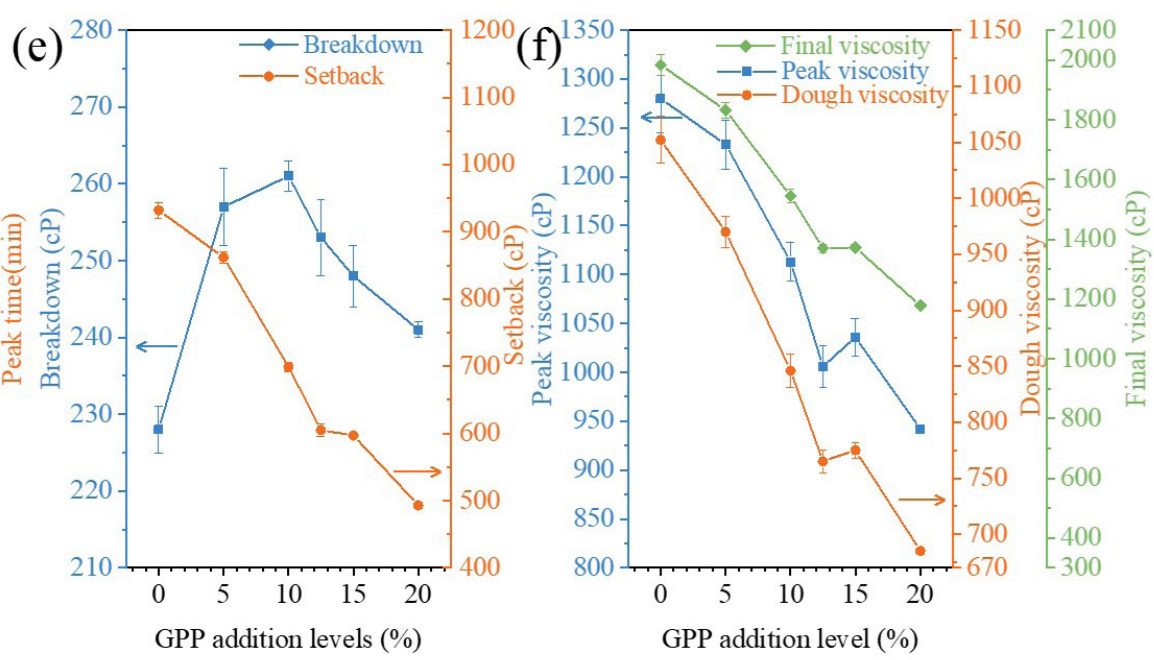

Figure 1. Effects of GPP on rheological and pasting properties of dough

gluten strength outweighed weakening, resulting in a general improvement in global gluten strength, thereby facilitating subsequent dough processing.

\subsection{Pasting properties of dough}

The pasting properties of flours are particularly important in the cookie-making process, Figure 1 depicts the effect of GPP on the pasting properties of dough. As shown in Figure 1d, compared with the control group, increase in GPP concentration among all studied levels did not significantly influence the pasting temperatures. According to literature (Maniñgat \& Juliano, 2010; Marshall et al., 1990), both lipids and proteins can improve the starch gelatinization temperature by forming complex with starch, resulting in a slower swelling of the starch granules, therefore, the fluctuation of gelatinization temperature 
of composite powder in a minor range is attributed to the protein and lipid contained in grape pomace.

Breakdown viscosity refers to difference between the peak and trough viscosity. As the breakdown value reflects the starch grain stability, lower values lead to a higher thermal stability of the paste and better shear and agitation resistance (Shahzad et al., 2019). The setback parameter is the difference between the final viscosity and trough viscosity, indicating the starch retrogradation during the cooling stage (i.e. degree of aging). The large setback value relates to high reassociation of amylose molecules in the paste (Xiong et al., 2021). Starch pastes with GPP concentration under study were ruptured to higher extent than control, because their breakdown viscosity values were also higher (Figure 1e), thus probably making the GPP pastes less resistant to thermal and mechanical disruption (Gałkowska et al., 2013). Since the measurement conditions of the pastes were the same, it is assumed that the difference in fragmentation degree depends on the properties of particles. Compared with that of the control group, the setback value was significantly lower in GPP groups $(\mathrm{p}<0.05)$ and decreased with increasing GPP levels. Because starch granules have similar amylose / amylopectin ratios, the short-term retrogradation tendency of GPP paste is low, which may be due to the interaction between polyphenols, lipids in GPP and starch granules, thus space steric hindrance reduces the trend of scattered, linear debris rearrangement (Krishnan et al., 2021; Gao et al., 2021). Starch particles are usually insoluble in water when the temperature is below $50{ }^{\circ} \mathrm{C}$. However, when a certain temperature is reached, starch particles show considerable water absorption and simultaneously expand in volume to several times the initial value, resulting in a sudden increase in viscosity. The trough viscosity was derived at $95{ }^{\circ} \mathrm{C}$ under agitation, at which point starch grains were broken into small molecules and rearranged in solution. The final viscosity is the value determined at $50^{\circ} \mathrm{C}$ after cooling. The peak, trough, and final viscosities are associated with the starch particle morphology, amylose to amylopectin ratio, relative molecular weight, and starch particle size, among other factors (Al-Ansi et al., 2021). Upon cooling stage, because the increased hydrogen bonding under low temperatures (Kim et al., 1997), the viscosity of the paste increased rapidly. These three viscosities decreased significantly ( $\mathrm{p}<0.05$ ) as GPP increased (Figure 1f), majorly due to the starch dilution effect in GPP pastes, which leads to a decrease in dough stability (Biao et al., 2019).

\subsection{Sensory evaluation}

A sensory evaluation of biscuits with various GPP contents is summarized in Table 1 . With respect to appearance and texture, there were no significant differences between the GPP groups and the control group. With respect to colour, the score differed significantly between the $5 \mathrm{wt} \%$ group and the control group ( $\mathrm{p}<0.05$ ), with values of 7.85 and 8.25 , respectively, while there was no difference between the scores for $10 \mathrm{wt} \%$ (7.30) or $12.5 \mathrm{wt} \%$ (7.75) compared with $5 \mathrm{wt} \%$ (7.75). The appearance scores showed a similar trend to that of colour scores, which could probably be explained by the influence of the latter on the former, to a certain degree. This was consistent with results of a previous study (Ajila et al., 2008). In this study, the colour score increased slightly when the GPP level reached $12.5 \mathrm{wt} \%$, reflecting a favourable chocolate colour. When GPP exceeded $12.5 \mathrm{wt} \%$, a rough granular surface was clearly observed, along with an astringency, thus contributing to reduced scores. In terms of flavour, at $10 \mathrm{wt} \%$, the score was highest (8.05), and increases in GPP led to decreased scores. Accordingly, 10 wt $\%$ GPP conferred a sufficient grape flavour and was favourable to consumers. This was similar to previous results (Kohajdová et al., 2014), wherein apple pomace was used to improve biscuit fragrance. With regard to texture, increasing GPP resulted in a decreased score, which could probably be attributed to a reduced size and elevated surface roughness. For GPP below $12.5 \mathrm{wt} \%$, acceptability did not differ substantially from that of the control group, suggesting that the biscuits could be accepted by consumers. Overall, using $10 \mathrm{wt} \%$ GPP, the corresponding biscuits exhibited a chocolate colour, regular appearance, relatively smooth surface, rich fragrance, appropriate grape taste, crispy characteristic, and distinct crosssection structure with small and well-distributed pores, among other features.

\subsection{Biscuit colour measurement}

Table 2 shows the results of colour measurements of biscuits made with different levels of GPP preparations. Compared with those of the control group, the values of $\mathrm{L}^{*}$ and $\mathrm{b}^{*}$ were significantly lower in GPP groups $(\mathrm{p}<0.05)$, and decreased as GPP increased $(\mathrm{p}<0.05)$, indicating a reduced brightness and lustrousness and increased degree of blue colour. This effect was mainly due to natural pigments such as anthocyanins in GPP (Aksoylu et al., 2015). In contrast, the value of $a^{*}$ displayed the opposite trend, suggesting an increased degree of red. Combining

Table 1. Sensory evaluation of biscuits incorporated with grape pomace powder.

\begin{tabular}{|c|c|c|c|c|c|}
\hline \multirow{2}{*}{ Addition level (wt\%) } & \multicolumn{5}{|c|}{ evaluation score } \\
\hline & colour & appearance & flavour & texture & acceptability \\
\hline 0 & $8.25 \pm 0.80^{\mathrm{a}}$ & $8.05 \pm 0.83^{\mathrm{a}}$ & $7.75 \pm 0.75^{\mathrm{a}}$ & $7.85 \pm 0.89^{a}$ & $8.00 \pm 0.74^{\mathrm{a}}$ \\
\hline 5 & $7.85 \pm 0.75^{\mathrm{ab}}$ & $7.65 \pm 1.05^{\mathrm{a}}$ & $7.65 \pm 0.88^{\mathrm{a}}$ & $7.60 \pm 0.77^{a}$ & $7.45 \pm 0.32^{\mathrm{a}}$ \\
\hline 10 & $7.30 \pm 1.00^{\mathrm{ab}}$ & $7.70 \pm 0.94^{\mathrm{a}}$ & $8.05 \pm 0.93^{\mathrm{a}}$ & $7.66 \pm 0.85^{\mathrm{a}}$ & $7.85 \pm 0.45^{\mathrm{a}}$ \\
\hline 12.5 & $7.75 \pm 0.96^{\mathrm{ab}}$ & $7.85 \pm 1.00^{\mathrm{a}}$ & $7.55 \pm 0.76^{\mathrm{a}}$ & $7.35 \pm 0.73^{\mathrm{a}}$ & $7.60 \pm 0.47^{\mathrm{a}}$ \\
\hline 15 & $6.25 \pm 1.02^{\mathrm{b}}$ & $7.35 \pm 0.75^{\mathrm{a}}$ & $5.85 \pm 0.78^{\mathrm{b}}$ & $6.65 \pm 0.84^{\mathrm{a}}$ & $7.15 \pm 1.01^{\mathrm{ab}}$ \\
\hline 20 & $4.20 \pm 0.85^{c}$ & $7.20 \pm 0.89^{\mathrm{a}}$ & $4.45 \pm 0.56^{c}$ & $6.35 \pm 0.48^{\mathrm{a}}$ & $6.10 \pm 0.94^{\mathrm{b}}$ \\
\hline
\end{tabular}

Values are means \pm SD of three independent determinations. Means followed by different superscript letters within a column are significantly $(p<0.05)$ different. 
the results of the colour analysis with a sensory evaluation of colour could enable rational quality estimation.

\subsection{Textural properties of biscuit}

Hardness is the force needed for sample deformation (Zhang et al., 2020). Fracturability refers to the force at which a sample cracks during the first compression, it is negatively correlated with the crispy characteristic in a sensory evaluation (Mohsen et al., 2010). Chewiness depicts the force required to transform a sample from a chewable state to a swallowable state. These parameters are closely related to human perception of freshness, thereby attracted much attention in the evaluation of baking products (Kuchtová et al., 2018), as shown in Table 2, hardness displayed maximum value at $15 \mathrm{wt} \% \mathrm{GPP}$, which was significantly higher than the control group. Our results was different form the report by Kuchtová et al. (2018). This phenomenon was probably related to the linkage between polyphenols in GPP and protein or starch, leading to an increased gluten network strength and improved dough strength (Zhang et al., 2010), which consistent with previous rheological results. Further increase in GPP resulted in reduced relative gluten protein contents, thereby decreasing hardness. Chewiness displayed a trend identical to that of hardness. Fracturability increased with increasing GPP. Generally, lower hardness is more easily accepted by consumers (Assis et al., 2009). In view of this, the addition of grape pomace should be minimized to ensure that biscuits are within acceptable hardness.

\subsection{General composition of biscuit}

Table 3 summarizes the general composition of biscuits with different GPP contents. Compared with the control group, GPP groups showed significantly higher $(p<0.05)$ crude protein, crude fat, and total polyphenol contents. When $12.5 \mathrm{wt} \%$ GPP was used, levels of these three components increased $14.01 \%$, $24.79 \%$, and $44.59 \%$, respectively; for $20 \mathrm{wt} \%$, these increased by $25.14 \%, 31.96 \%$, and $71.62 \%$, respectively. The total dietary fiber content was positively correlated with the GPP content. According to the claim a foodstuff contains a high fiber content may be given only if the product has at least $6 \mathrm{~g}$ of fiber per $100 \mathrm{~g}$ that pointed out by regulation of the European Parliament of the Council (EC). The ash and water contents did not differ significantly between the GPP groups and the control group. Taken together, Cookies incorporated with an amount of $\geq$ $10 \mathrm{wt} \%$ GPP can be considered as a high fiber content food.

\subsection{Antioxidant properties of biscuits}

The antioxidant activity of biscuits with GPP are shown in Figure 2. Compared with those in the control group, DPPH and hydroxyl radical scavenging activities were significantly higher $(\mathrm{p}<0.05)$ and increased as the GPP content increased. For $5 \mathrm{wt} \%$ GPP, scavenging activity on DPPH and hydroxyl radicals increased by $40.95 \%$ and $47.01 \%$ over that in the control, respectively. In addition, the observed increases with increasing GPP levels suggested the excellent antioxidant effect of GPP in vitro. These results were consistent with those of Santa Cruz Olivos et al. (2021). Reducing activity (Figure 2b) increased with increasing GPP, with an increase in polyphenol content. Accordingly, GPP could be a promising natural antioxidant, improving the shelf life and quality of biscuit products.

\subsection{In vitro digestion characteristics}

Based on the Englyst method, starch can be categorized into RDS, SDS, and RS. Table 4 shows the RDS, SDS, and RS contents in biscuits made with GPP. In all biscuits, the RS content

Table 2. Textural properties and colour measurement of biscuits.

\begin{tabular}{ccccccc}
\hline Addition level (\%) & Hardness (g) & Chewiness (g) & Fracturability (g) & $\mathrm{L}^{*}$ & $\mathrm{a}^{\star}$ & $\mathrm{b}^{\star}$ \\
\hline 0 & $2810.24 \pm 125^{\mathrm{e}}$ & $34.80 \pm 6^{\mathrm{e}}$ & $651.28 \pm 90^{\mathrm{f}}$ & $68.58 \pm 0.15^{\mathrm{a}}$ & $6.22 \pm 0.03^{\mathrm{e}}$ & $29.84 \pm 0.02^{\mathrm{a}}$ \\
5 & $3051.12 \pm 136^{\mathrm{d}}$ & $265.15 \pm 83^{\mathrm{d}}$ & $1052.33 \pm 43^{\mathrm{e}}$ & $57.40 \pm 0.23^{\mathrm{b}}$ & $6.38 \pm 0.14^{\mathrm{d}}$ & $19.59 \pm 0.06^{\mathrm{b}}$ \\
10 & $4821.75 \pm 158^{\mathrm{c}}$ & $702.44 \pm 150^{\mathrm{c}}$ & $1257.23 \pm 47^{\mathrm{d}}$ & $49.08 \pm 0.72^{\mathrm{c}}$ & $8.38 \pm 0.15^{\mathrm{c}}$ & $17.15 \pm 0.12^{\mathrm{c}}$ \\
12.5 & $5639.23 \pm 246^{\mathrm{b}}$ & $1354.36 \pm 109^{\mathrm{b}}$ & $2349.50 \pm 88^{\mathrm{c}}$ & $48.73 \pm 0.46^{\mathrm{c}}$ & $8.67 \pm 0.16^{\mathrm{bc}}$ & $16.80 \pm 0.23^{\mathrm{cd}}$ \\
15 & $6577.13 \pm 379^{\mathrm{a}}$ & $1854.47 \pm 88^{\mathrm{a}}$ & $2638.28 \pm 89^{\mathrm{b}}$ & $47.82 \pm 0.16^{\mathrm{d}}$ & $8.99 \pm 0.22^{\mathrm{b}}$ & $16.48 \pm 0.04^{\mathrm{d}}$ \\
20 & $4696.01 \pm 375^{\mathrm{c}}$ & $685.20 \pm 90^{\mathrm{c}}$ & $3174.39 \pm 101^{\mathrm{a}}$ & $43.60 \pm 0.51^{\mathrm{e}}$ & $9.87 \pm 0.08^{\mathrm{a}}$ & $14.14 \pm 0.06^{\mathrm{e}}$ \\
\hline
\end{tabular}

Values are means \pm SD of three independent determinations. Means followed by different superscript letters within a column are significantly $(p<0.05)$ different.

Table 3. General composition of biscuits.

\begin{tabular}{|c|c|c|c|c|c|c|}
\hline \multirow{2}{*}{ Component (\%) } & \multicolumn{6}{|c|}{ GPP addition level (wt\%) } \\
\hline & 0 & 5 & 10 & 12.5 & 15 & 20 \\
\hline Moisture & $1.85 \pm 0.32^{\mathrm{ab}}$ & $2.14 \pm 0.25^{\mathrm{a}}$ & $1.36 \pm 0.28^{b}$ & $2.01 \pm 0.54^{\mathrm{ab}}$ & $1.47 \pm 0.52^{\mathrm{ab}}$ & $1.33 \pm 0.34^{\mathrm{b}}$ \\
\hline Ash & $2.08 \pm 0.13^{\mathrm{a}}$ & $2.21 \pm 0.28^{\mathrm{a}}$ & $2.38 \pm 0.33^{\mathrm{a}}$ & $1.67 \pm 0.48^{\mathrm{a}}$ & $1.83 \pm 0.36^{\mathrm{a}}$ & $2.02 \pm 0.42^{\mathrm{a}}$ \\
\hline Crude fat & $9.48 \pm 0.38^{\mathrm{d}}$ & $9.43 \pm 0.26^{\mathrm{d}}$ & $10.24 \pm 0.14^{\mathrm{c}}$ & $11.83 \pm 0.25^{\mathrm{b}}$ & $11.96 \pm 0.18^{\mathrm{b}}$ & $12.51 \pm 0.33^{\mathrm{a}}$ \\
\hline Crude protein & $8.99 \pm 0.46^{\mathrm{d}}$ & $9.00 \pm 0.32^{\mathrm{d}}$ & $9.58 \pm 0.24^{c}$ & $10.25 \pm 0.14^{\mathrm{b}}$ & $10.63 \pm 0.12^{\mathrm{b}}$ & $11.25 \pm 0.06^{\mathrm{a}}$ \\
\hline Total carbohydrate & $68.45 \pm 3.78^{\mathrm{a}}$ & $65.32 \pm 5.23^{\mathrm{a}}$ & $61.74 \pm 3.57^{\mathrm{ab}}$ & $61.80 \pm 5.25^{\mathrm{ab}}$ & $56.21 \pm 3.60^{\mathrm{bc}}$ & $53.47 \pm 4.24^{c}$ \\
\hline Total polyphenols & $0.74 \pm 0.05^{c}$ & $0.82 \pm 0.14^{c}$ & $0.99 \pm 0.03^{b}$ & $1.07 \pm 0.11^{\mathrm{b}}$ & $1.23 \pm 0.05^{\mathrm{a}}$ & $1.27 \pm 0.12^{\mathrm{a}}$ \\
\hline TDF & $0.92 \pm 0.05^{\mathrm{f}}$ & $4.12 \pm 0.12^{\mathrm{e}}$ & $6.53 \pm 0.14^{\mathrm{d}}$ & $7.98 \pm 0.32^{c}$ & $9.05 \pm 0.27^{\mathrm{b}}$ & $11.21 \pm 0.45^{\mathrm{a}}$ \\
\hline
\end{tabular}

Values are means \pm SD of three independent determinations. Means followed by different superscript letters within a column are significantly $(p<0.05)$ different. 


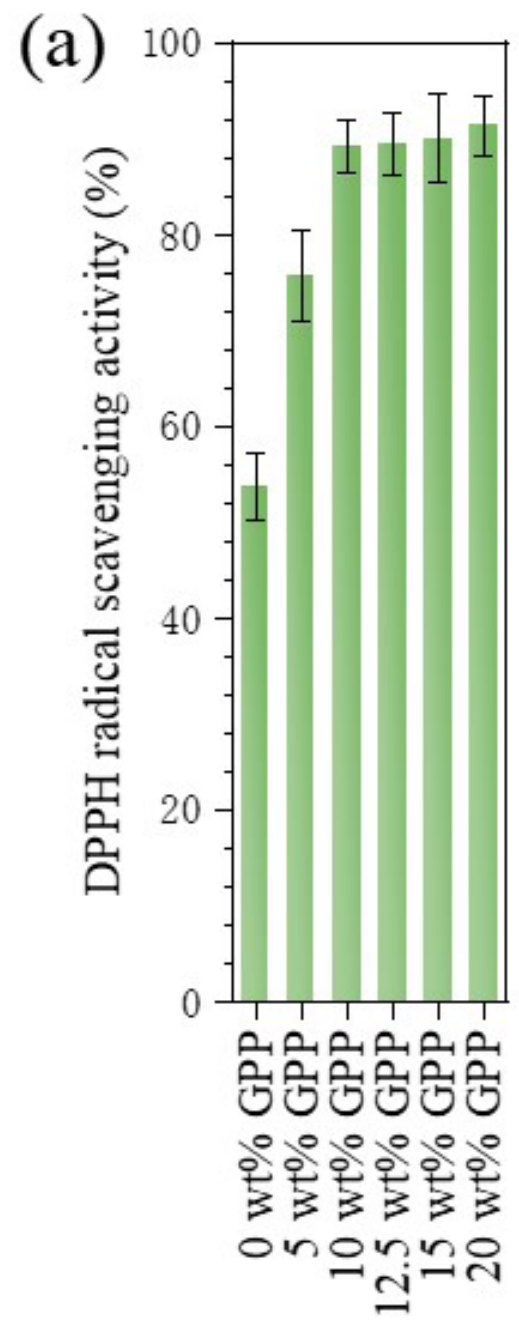

(b)

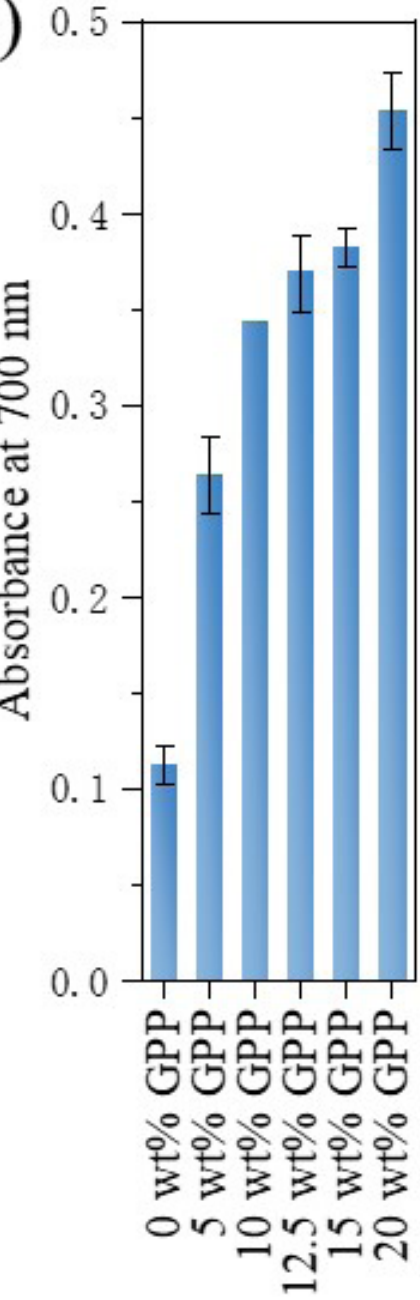

(c)

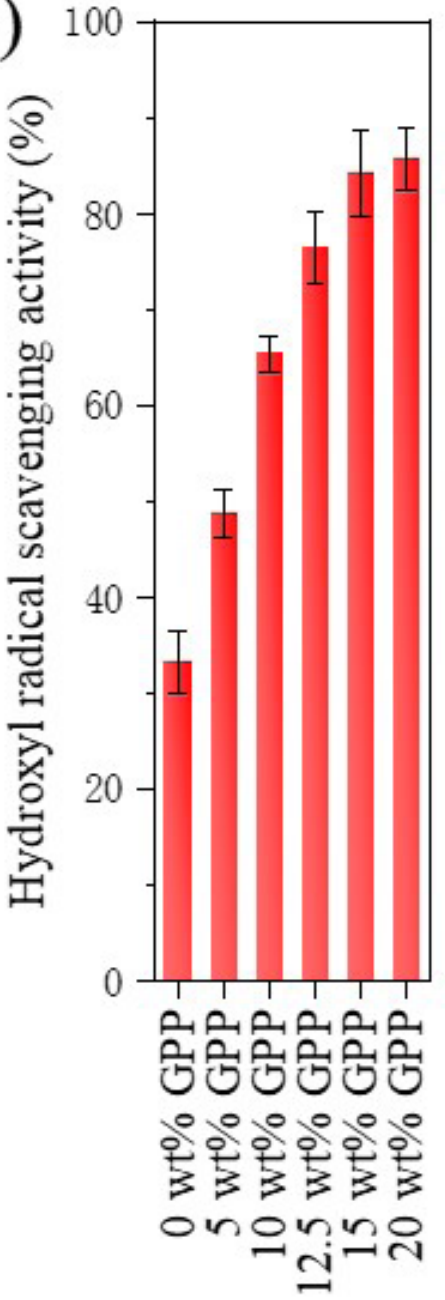

Figure 2. Chemical antioxidant activities of biscuits with various GPP amounts. (a) DPPH radical scavenging activity, (b) reducing power, and (c) hydroxyl radical scavenging activity

Table 4. Starch composition and hydrolysis parameters for biscuits.

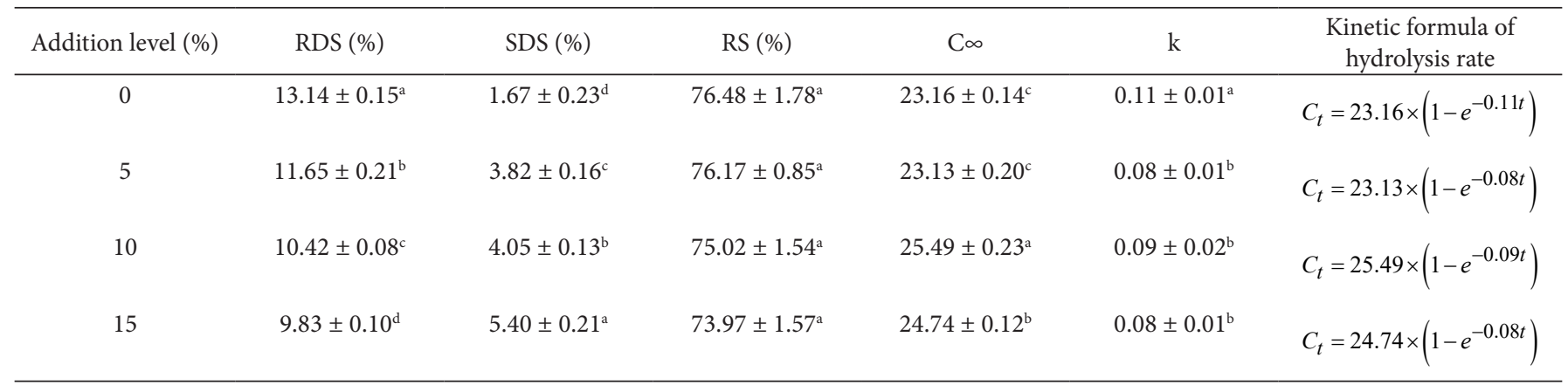

Values are means \pm SD of three independent determinations. Means followed by different superscript letters within a column are significantly $(p<0.05)$ different.

ranged between $73 \%$ and $77 \%$, which is the main component of biscuit starch. The RS contents related incomplete starch gelatinization and the occurrence of starch retrogradation during cooling phase (Agama-Acevedo et al., 2019; Palavecino et al.,
2019). Interestingly, the RS content measured here in biscuit is 35 -fold higher than that in GP-fortified pasta reported by Tolve et al. (2020). This difference indicates once again that there are incompletely gelatinized and undigestible starch fraction in 

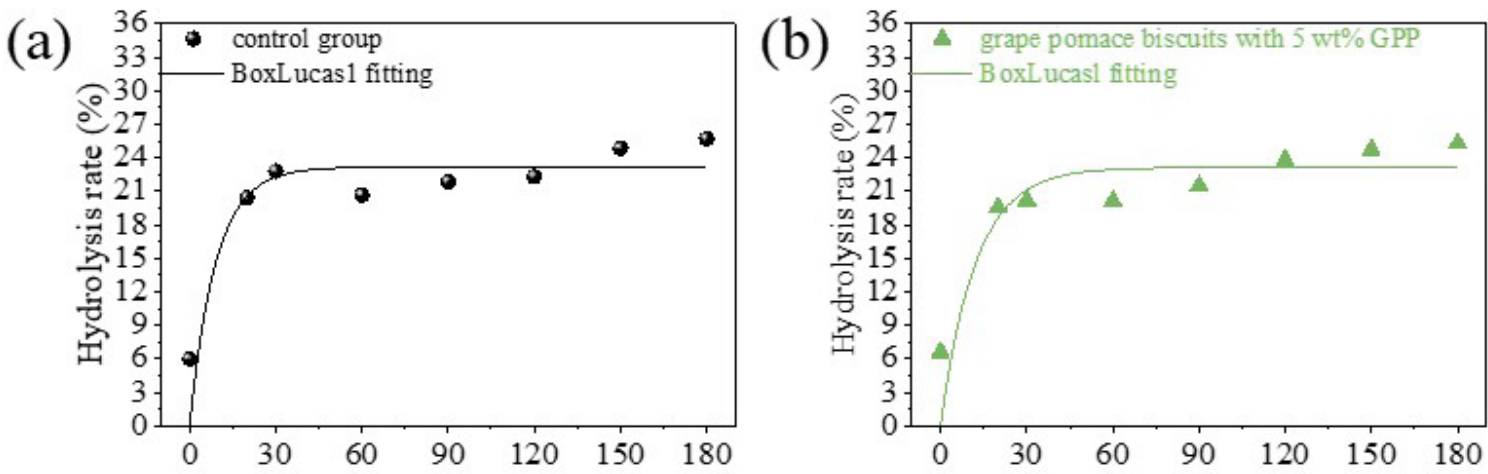

Hydrolysis time (min)

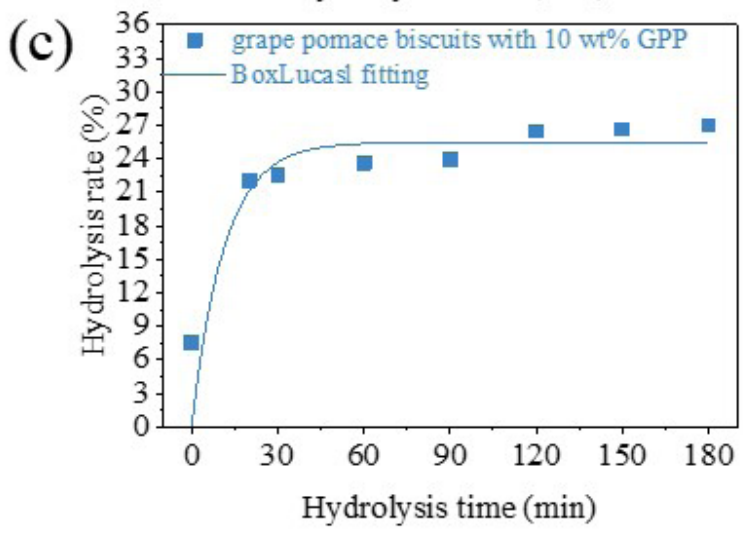

(d)

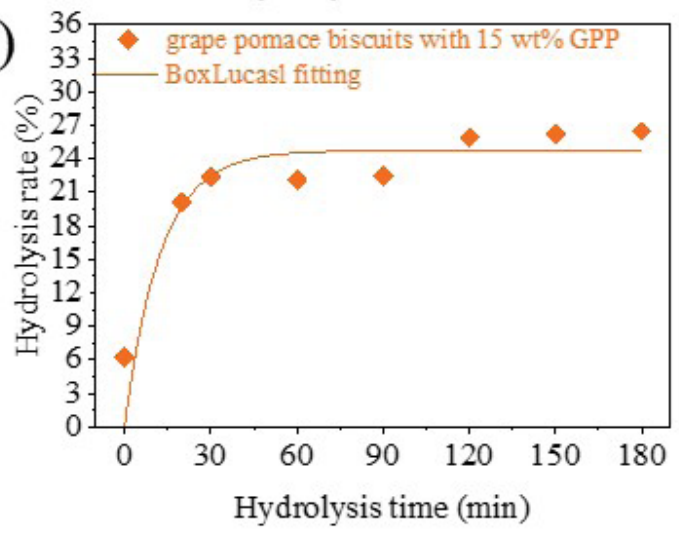

Figure 3. Kinetics of the enzymatic digestion of biscuits

biscuit products, and this incomplete gelatinization of starch is related to water consumption. Moreover, this difference cannot ignore the influence of different processing techniques of various products and the composition discrepancy of flour on RS content. A slight but significantly reduction of reaction constants (i.e. k) and RDS(table 4)suggested that the structure arrangement of starch components in GPP enhanced biscuits was more extensive, which limited the hydrolysis of digestive enzymes (Agama-Acevedo et al., 2019; Williamson, 2013; Palavecino et al., 2019; Li et al., 2020). The lower reaction constant in grape pomace biscuits is consistent with its lower RS content. However, the sum of RS and SDS account for 78\% - $80 \%$ of total starch, and they are the main ingredients of biscuits. From this perspective, grape pomace can be used as a potentially healthy food processing ingredient.

Figure 3 displays the in vitro digestion rate curves of biscuits with and without GPP. No significant difference was observed in the samples with different GPP additions compared with the control group. In all cases, within the first $45 \mathrm{~min}$ of the reaction, the hydrolysis rate rapidly and continuously increased, and then decreased until $120 \mathrm{~min}$, the hydrolysis rate further decreased. However, The predicted glycemic index was calculated by using the empiric equation $\mathrm{pGI}=39.71+0.549(\mathrm{HI} 90)(\mathrm{r}=$ 0.96) (Goñi et al., 1996). It was found that all the biscuis include control was surprisingly high $(\geq 90)$, therefore, further in vivo studies are needed to clarify the actual postprandial blood glucose response of the cookies.

\section{Conclusions}

The impacts of various amounts of GPP were systematically evaluated, including analyses of rheological and pasting properties of dough as well as the quality of the final biscuit product, focusing on sensory characteristics, nutritional properties, digestive and antioxidant activities. With respect to rheological properties, GPP reduced the water absorption for dough formation but increased development time and dough stability. GPP at greater than $5 \mathrm{wt} \%$ increased gluten strength, thereby facilitated the dough processing properties. GPP addition had limited effect on pasting temperature but significantly decreased the setback value of the paste system, which indicated that active polyphenol fraction in grape pomace can effectively prevent amylose association in starch paste upon cooling stage. However, an increase of breakdown viscosity suggested that GPP could reduce the thermal stability and mechanical damage resistance of starch granules. A sensory evaluation suggested that less than $12.5 \mathrm{wt} \%$ GPP does not significantly affect acceptability and $10 \mathrm{wt} \%$ GPP delivered the best taste with a grape flavour. An in vitro antioxidant activity test indicated that GPP could significantly improve antioxidant activity of biscuit. GPP addition had minor influence on digestibility but significantly increased dietary fiber and polyphenol contents of biscuit. And up to $10 \mathrm{wt} \% \mathrm{GPP}$ in biscuits makes it meet the needs of modern "high dietary fiber" healthy food. Taken together, these results provide valuable insights into the effects of GPP on biscuit production and thus provide a basis for its effective utilization in the food industry. 


\section{Conflicts of interest}

The authors declare no conflict of interest.

\section{Acknowledgements}

This research was supported by the Science and Technology Research Program of Henan Province (grant number 202102310143).

\section{References}

AACC International (2000). Approved methods of the American Association of cereal chemists (10th ed., Methods 44-15, 08-01, 4611, 30-10, 80-68, 54-21, 38-12, 44-19). St. Paul, MN: The American Association of Cereal Chemist, Inc.

Agama-Acevedo, E., Pacheco-Vargas, G., Gutierrez-Meraz, F., Tovar, J., \& Bello-Perez, L. A. (2019). Dietary fiber content, texture, and in vitro starch digestibility of different white bread crusts. Journal of Cereal Science, 89, 102824. http://dx.doi.org/10.1016/j.jcs.2019.102824.

Ajila, C. M., Leelavathi, K., \& Prasada Rao, U. J. S. (2008). Improvement of dietary fiber content and antioxidant properties in soft dough biscuits with the incorporation of mango peel powder. Journal of Cereal Science, 48(2), 319-326. http://dx.doi.org/10.1016/j.jcs.2007.10.001.

Aksoylu, Z., Çağindi, Ö., \& Köse, E. (2015). Effects of blueberry, grape seed powder and poppy seed incorporation on physicochemical and sensory properties of biscuit. Journal of Food Quality, 38(3), 164-174. http://dx.doi.org/10.1111/jfq.12133.

Al-Ansi, W., Sajid, B. M., Mahdi, A. A., Al-Maqtari, Q. A., Al-Adeeb, A., Ahmed, A., Fan, M., Li, Y., Qian, H., Jinxin, L., \& Wang, L. (2021). Molecular structure, morphological, and physicochemical properties of highlands barley starch as affected by natural fermentation. Food Chemistry, 356, 129665. http://dx.doi.org/10.1016/j. foodchem.2021.129665. PMid:33813206.

Aly, A. A., El-Deeb, F. E., Abdelazeem, A. A., Hameed, A. M., Abdulaziz Alfi, A., Alessa, H., \& Alrefaei, A. F. (2021). Addition of whole barley flour as a partial substitute of wheat flour to enhance the nutritional value of biscuits. Arabian Journal of Chemistry, 14(5), 103112. http:// dx.doi.org/10.1016/j.arabjc.2021.103112.

Anil, M. (2007). Using of hazelnut testa as a source of dietary fiber in breadmaking. Journal of Food Engineering, 80(1), 61-67. http:// dx.doi.org/10.1016/j.jfoodeng.2006.05.003.

AOAC International. (2000). Official methods of analysis of AOAC international (17th ed., Method 991.43), Gaithersburg, MD, USA: AOAC International.

Ar1 Akin, P., Tayfun, K. E., Tamer, U., \& Boyac1, İ. H. (2021). Use of tea fibers as a source of dietary fiber in wheat flour and bread. Cereal Chemistry, 00, 1-10.

Assis, L. M., Zavareze, E., Radúnz, A., Dias, Á., Gutkoski, L., \& Elias, M. (2009). Propriedades nutricionais, tecnológicas e sensoriais de biscoitos com substituição de farinha de trigo por farinha de aveia ou farinha de arroz parboilizado. Alimentos e Nutrição, 20, 15-24.

Biao, Y., Chen, X., Wang, S., Chen, G., Mcclements, D. J., \& Zhao, L.. (2019). Impact of mushroom (pleurotus eryngii) flour upon quality attributes of wheat dough and functional cookies-baked products. Food Science \& Nutrition, 8(1), 361-370. http://dx.doi.org/10.1002/ fsn3.1315. PMid:31993162.

Blanco Canalis, M. S., Baroni, M. V., León, A. E., \& Ribotta, P. D. (2020). Effect of peach puree incorportion on cookie quality and on simulated digestion of polyphenols and antioxidant properties. Food Chemistry, 333, 127464. http://dx.doi.org/10.1016/j.foodchem.2020.127464. PMid:32659667.
Chamorro, S., Viveros, A., Alvarez, I., Vega, E., \& Brenes, A. (2021). Changes in polyphenol and polysaccharide content of grape seed extract and grape pomace after enzymatic treatment. Food Chemistry, 133(2), 308-314. http://dx.doi.org/10.1016/j.foodchem.2012.01.031.

Chimi, H., Cillard, J., Cillard, P., \& Rahmani, M. (1991). Peroxyl and hydroxyl radical scavenging activity of some natural phenolic antioxidants. Journal of the American Oil Chemists' Society, 68(5), 307-312. http://dx.doi.org/10.1007/BF02657682.

Devinder, D., Mona, M., \& Hradesh, R. (2012). Physico-chemical characteristics of dietary fibre from potato peel and its effect on organoleptic characteristics of biscuits. Journal of Agricultural Engineering, 49(4), 25-32.

Englyst, H. N., Kingman, S. M., \& Cummings, J. H. (1992). Classification and measurement of nutritionally important starch fractions. European Journal of Clinical Nutrition, 46(Suppl 2), S33-S50. PMid:1330528.

Gałkowska, D., Długosz, M., \& Juszczak, L. (2013). Effect of high methoxy pectin and sucrose on pasting, rheological, and textural properties of modified starch systems. Stärke, 65(5-6), 499-508. http://dx.doi.org/10.1002/star.201200148

Gao, L., Zhang, C., Chen, J., Liu, C., Dai, T., Chen, M., \& Li, T. (2021). Effects of proanthocyanidins on the pasting, rheological and retrogradation properties of potato starch. Journal of the Science of Food and Agriculture, 101(11), 4760-4767. http://dx.doi.org/10.1002/ jsfa.11122. PMid:33502770.

Girard, A. L., Castell-Perez, M. E., Bean, S. R., Adrianos, S. L., \& Awika, J. M. (2016). Effect of Condensed Tannin Profile on Wheat Flour Dough Rheology. Journal of Agricultural and Food Chemistry, 64(39), 7348-7356. http://dx.doi.org/10.1021/acs.jafc.6b02601. PMid:27616442.

Goñi, I., García-Diz, L., Mañas, E., \& Saura-Calixto, F. (1996). Analysis of resistant starch: a method for foods and food products. Food Chemistry, 56(4), 445-449. http://dx.doi.org/10.1016/0308-8146(95)00222-7.

Han, H. M., \& Koh, B. K. (2011). Effect of phenolic acids on the rheological properties and proteins of hard wheat flour dough and bread. Journal of the Science of Food and Agriculture, 91(13), 2495 2499. http://dx.doi.org/10.1002/jsfa.4499. PMid:21732382.

Kim, Y. S., Wiesenborn, D. P., \& Grant, L. A. (1997). Pasting and thermal properties of potato and bean starches. Stärke, 49(3), 97-102. http:// dx.doi.org/10.1002/star.19970490304.

Kohajdová, Z., Karovičová, J., Magala, M., \& Kuchtová, V. (2014). Effect of apple pomace powder addition on farinographic properties of wheat dough and biscuits quality. Chemical Papers, 68(8), 1059-1065. http://dx.doi.org/10.2478/s11696-014-0567-1.

Krishnan, V., Mondal, D., Thomas, B., Singh, A., \& Praveen, S. (2021). Starch-lipid interaction alters the molecular structure and ultimate starch bioavailability: a comprehensive review. International Journal of Biological Macromolecules, 182, 626-638. http://dx.doi.org/10.1016/j. ijbiomac.2021.04.030. PMid:33838192.

Kuchtová, V., Kohajdová, Z., Karoviová, J., \& Lauková, M. (2018). Physical, textural and sensory properties of cookies incorporated with grape skin and seed preparations. Polish Journal of Food and Nutrition Sciences, 68(4)

Lee, S. J., Choi, S. K., \& Seo, J. S. (2009). Grape skin improves antioxidant capacity in rats fed a high fat diet. Nutrition Research and Practice, 3(4), 279-285. http://dx.doi.org/10.4162/nrp.2009.3.4.279. PMid:20098580.

Li, Y., Lv, J., Wang, L., Zhu, Y., \& Shen, R. (2020). Effects of millet bran dietary fiber and millet flour on dough development, steamed bread quality, and digestion in vitro. Applied Sciences (Basel, Switzerland), 10(3), 912. http://dx.doi.org/10.3390/app10030912. 
Liang, Z., Pai, A., Liu, D., Luo, J., Wu, J., Fang, Z., \& Zhang, P. (2020). Optimizing extraction method of aroma compounds from grape pomace. Journal of Food Science, 85(12), 4225-4240. http://dx.doi. org/10.1111/1750-3841.15533. PMid:33190228.

Mahasukhonthachat, K., Sopade, P. A., \& Gidley, M. J. (2010). Kinetics of starch digestion in sorghum as affected by particle size. Journal of Food Engineering, 96(1), 18-28. http://dx.doi.org/10.1016/j. jfoodeng.2009.06.051.

Maniñgat, C. C., \& Juliano, B. O. (2010). Starch lipids and their effect on rice starch properties. Stärke, 32(3), 76-82. http://dx.doi.org/10.1002/ star. 19800320303.

Marshall, W. E., Normand, F. L., \& Goynes, W. R. (1990). Effects of lipid and protein removal on starch gelatinization in whole grain milled rice. Cereal Chemistry, 67(5), 458-463.

Mildner-Szkudlarz, S., Bajerska, J., Zawirska-Wojtasiak, R., \& Gorecka, D. (2013). White grape pomace as a source of dietary fibre and polyphenols and its effect on physical and nutraceutical characteristics of wheat biscuits. Journal of the Science of Food and Agriculture, 93(2), 389-395. http://dx.doi.org/10.1002/jsfa.5774. PMid:22806270.

Mildner-Szkudlarz, S., Zawirska-Wojtasiak, R., \& Gośliński, M. (2010). Phenolic compounds from winemaking waste and its antioxidant activity towards oxidation of rapeseed oil. International Journal of Food Science \& Technology, 45(11), 2272-2280. http://dx.doi. org/10.1111/j.1365-2621.2010.02397.x.

Mironeasa, S., Codina, G. G., \& Mironeasa, C. (2012). The effect of wheat flour substitution with grape seed flour on the rheological parameters of the dough assessed by Mixolab. Journal of Texture Studies, 43(1), 40-48. http://dx.doi.org/10.1111/j.1745-4603.2011.00315.x.

Mohsen, S. M., Fadel, H. H. M., Bekhit, M. A., Edris, A. E., \& Ahmed, M. Y. S. (2010). Effect of substitution of soy protein isolate on aroma volatiles, chemical composition and sensory quality of wheat cookies. International Journal of Food Science \& Technology, 44(9), 1705-1712. http://dx.doi.org/10.1111/j.1365-2621.2009.01978.x.

Moon, Y., \& Kweon, M. (2021). Potential application of enzymes to improve quality of dry noodles by reducing water absorption of inferior-quality flour. Food Science and Biotechnology, 30 (7), 921-930. http://dx.doi.org/10.1007/s10068-021-00936-6. PMid:34395023.

Nogueira, A., Aguiar, E., Capriles, V. D., \& Steel, C. J. (2021). Correlations among src, mixolab, process, and technological parameters of protein-enriched biscuits. Cereal Chemistry, 98(3), 716-728. http:// dx.doi.org/10.1002/cche.10415.

Nowshehri, J. A., Bhat, Z. A., \& Shah, M. Y. (2015). Blessings in disguise: bio-functional benefits of grape seed extracts. Food Research International, 77, 333-348. http://dx.doi.org/10.1016/j. foodres.2015.08.026.

Palavecino, P. M., Ribotta, P. D., León, A. E., \& Bustos, M. C.. (2019). Gluten-free sorghum pasta: starch digestibility and antioxidant capacity compared with commercial products. Journal of the Science of Food and Agriculture, 99(3), 1351-1357. http://dx.doi.org/10.1002/ jsfa.9310. PMid:30094850.

Pasqualone, A., Bianco, A. M., Paradiso, V. M., Summo, C., Gambacorta, G., \& Caponio, F. (2014). Physico-chemical, sensory and volatile profiles of biscuits enriched with grape marc extract. Food Research International, 65, 385-393. http://dx.doi.org/10.1016/j. foodres.2014.07.014.

Sakanaka, S., Tachibana, Y., Ishihara, N., \& Raj Juneja, L. (2004). Antioxidant activity of egg-yolk protein hydrolysates in a linoleic acid oxidation system. Food Chemistry, 86(1), 99-103. http://dx.doi. org/10.1016/j.foodchem.2003.08.014.

Santa Cruz Olivos, J. E., De Noni, I., Hidalgo, A., Brandolini, A., Yilmaz, V. A., Cattaneo, S., \& Ragg, E. M. (2021). Phenolic acid content and in vitro antioxidant capacity of einkorn water biscuits as affected by baking time. European Food Research and Technology, 247(3), 677-686. http://dx.doi.org/10.1007/s00217-020-03655-0.

Shahzad, S. A., Hussain, S., Mohamed, A. A., Alamri, M. S., Ibraheem, M. A., \& Qasem, A. A. A. (2019). Effect of hydrocolloid gums on the pasting, thermal, rheological and textural properties of Chickpea starch. Foods, 8(12), 687. http://dx.doi.org/10.3390/foods8120687. PMid:31888161.

Teixeira, A., Baenas, N., Dominguez-Perles, R., Barros, A., Rosa, E., Moreno, D. A., \& Garcia-Viguera, C. (2014). Natural bioactive compounds from winery by-products as health promoters: a review. International Journal of Molecular Sciences, 15(9), 15638-15678. http://dx.doi.org/10.3390/ijms150915638. PMid:25192288.

Tolve, R., Pasini, G., Vignale, F., Favati, F., \& Simonato, B. (2020). Effect of grape pomace addition on the technological, sensory, and nutritional properties of durum wheat pasta. Foods, 9(3), 354. http:// dx.doi.org/10.3390/foods9030354. PMid:32204341.

Wang, K., Wang, Y., Lin, S., Liu, X., Yang, S., \& Jones, G. S. (2015). Analysis of DPPH inhibition and structure change of corn peptides treated by pulsed electric field technology. Journal of Food Science and Technology, 52(7), 4342-4350. http://dx.doi.org/10.1007/s13197014-1450-3. PMid:26139899.

Williamson, G. (2013). Possible effects of dietary polyphenols on sugar absorption and digestion. Molecular Nutrition \& Food Research, 57(1), 48-57. http://dx.doi.org/10.1002/mnfr.201200511. PMid:23180627.

Xiong, X., Liu, C., Song, M., \& Zheng, X. (2021). Effect of characteristics of different wheat flours on the quality of fermented hollow noodles. Food Science \& Nutrition, (6), 1-11.

Yang, X., Croft, K. D., Lee, Y. P., Mori, T. A., Puddey, I. B., Sipsas, S., Barden, A., Swinny, E., \& Hodgson, J. M. (2010). The effects of a lupin-enriched diet on oxidative stress and factors influencing vascular function in overweight subjects. Antioxidants \& Redox Signaling, 13(10), 1517-1524. http://dx.doi.org/10.1089/ars.2010.3133. PMid:20214496.

Zhang, L., Cheng, L., Jiang, L., Wang, Y., Yang, G., \& He, G. (2010). Effects of tannic acid on gluten protein structure, dough properties and bread quality of Chinese wheat. Journal of the Science of Food and Agriculture, 90(14), 2462-2468. http://dx.doi.org/10.1002/ jsfa.4107. PMid:20718030.

Zhang, Z., Fan, X., Yang, X., Li, C., Gilbert, R. G., \& Li, E. (2020). Effects of amylose and amylopectin fine structure on sugar-snap cookie dough rheology and cookie quality. Carbohydrate Polymers, 241, 116371. http://dx.doi.org/10.1016/j.carbpol.2020.116371. PMid:32507168. 